\title{
DESTINATION BRANDING PROCESS EXAMPLED BY THE SOUTH COAST BALTIC REGION
}

\author{
Aleksandra Łapko* ำ http://orcid.org/0000-0003-0235-6329 \\ Martina Müller** (i) http://orcid.org/0000-0002-0435-3458
}

\begin{abstract}
Background. Destination branding is a complicated, long-lasting and challenging process because destination is the most complex tourist product which involves various other tourism products and various entities what requires a special approach.
\end{abstract}

Research aims. The basic aim of the article is to show using the example of the South Coast Baltic brand, how the process of a cross border umbrella tourist destination proceeds.

Methodology. Apart from the case study, the authors used such methods as: literature and documentation analysis and participant observation. Both authors are directly involved in marketing and pro-quality activities aimed at building the described brand. Therefore, the study is also based on practical knowledge about the subject discussed.

Key findings. The basic problem in the building a cross-border tourist destination brand such as South Coast Baltic is to take into account the differences between the countries and regions that make up the described brand. The brand creation process requires regular monitoring of the needs and preferences of the sailors in order to make the product identified best suited to their expectations.

Keywords: tourist brand, destination brand, South Coast Baltic, nautical tourism, tourism marketing.

JEL Codes: M31, L83, L0

\footnotetext{
* Faculty of Economics and Transport Engineering, Maritime University of Szczecin, H. Pobożnego 11, Szczecin 70-507, Poland. E-mail: a.lapko@am.szczecin.pl

** Pr-ide GbR, Public Relation \& Industrial Design, Sybelstr. 41, 10629 Berlin, Germany. E-mail: mmueller@pr-ide.de
} 


\section{INTRODUCTION}

Destination branding is a complicated, long-lasting and challenging process for all involved entities what makes it very interesting from the scientific point of view.

The basic aim of the article is to show how that process proceeds. It is done using the example of a destination composed of six regions belonging to five countries. The umbrella brand South Coast Baltic (SCB) was established in 2012 in the frame of an international project MARRIAGE and has been developing consequently in the South Coast Baltic project. In order for proper adaptation of undertaking activities to the needs of potential tourists, their needs and preferences are monitored and analysed. It gives a lot of unique information because the target groups are boaters - tourists that very seldom are subject of study.

The authors are participants of the SCB project responsible for marketing and pro quality activities which are crucial for the destination branding process.

The following research methods were used in the paper: critical analysis of the literature, the method of documentary research, mathematical and statistical methods, observation, and case study.

\section{LITERATURE REVIEW}

Issues related to branding and marketing in the area of tourist destinations are often mentioned in the scientific literature.

A destination which is an area tourist product can be regarded as the most important and complex structure in the tourism industry. If a destination is to be communicated as a brand, then it is necessary to coordinate the interests of the individual service providers (Scherhag, 2000, pp. 149-162; Kaczmarek et al., 2005).

There are different ways of looking at the term destination. The simplest depiction is that destination is a place that attracts visitors for a temporary stay (Dębski, 2013, pp. 41-50). The World Tourism Organisation (WTO) identifies the destination as a place or demarcated space that contains attractions, tourist facilities, and services selected by the traveller. Another definition is based on the existing boundaries 
of geographical areas independent on the national borderlines - such as the southern shores of the Baltic Sea, which is the subject of the article below. However, such an assignment for the term destination only makes sense if a uniform marketing of the respective defined destination takes place

Against this background the branding of a destination has certain features.

The American Marketing Association defines a brand as "a name, term, sign, symbol, design, or a combination of them intended to identify the goods and services of one seller or group of sellers and to differentiate them from those of competition" (Khan, 2009, p. 22).

The brand identifies a product and represents a promise of value. Brands incite beliefs, evoke emotions, and prompt behaviours. It is also important that brands can have a social and emotional value to users. They enhance the perceived utility and desirability of a product. Brands have the ability to add or subtract the perceived value of a product. Brand equity has been pointed out to include many dimensions, such as performance, social image, value, trustworthiness, and identification (Kotler \& Gertner, 2002, pp. 40-56; Michalski, 2017; Düssel, 2009). The destination brand expresses the image of the destination in the first place, makes curious on the whole and gives a certain expectation of performance, which may have the visitors (holiday form, experiences, and quality, here the individual marinas).

Brands definitely have an effect on consumer choice concerning tourism destination and considerations (Erdem \& Swait, 2004, pp. 191-198).

It is very important to draw attention that due to the fact that a destination is a complex system, destination branding cannot be treated as mere commodity branding.

Another difference between place branding and ordinary product branding is that it involves a lot of different entities. Brand building is not only about communicating with potential consumers through marketing messages, but also about the proper organisation of the entire tourism system, providing a comprehensive offer through cooperation between different stakeholders (Morgan et al., 2011; Campelo et al., 2013, pp. 154-166; Morgan et al., 2003, pp. 285-299). In addition, according to Dwyer \& Kim (2003, pp. 369-414) destination governance is one of the most important factors influencing the competiveness of a destination. They indicate establishing durable 
Destination Marketing Organization (DMO) as a crucial for success of destination brand strategy. DMO should involve: stakeholders that provide tourists services, policy makers, cultural organisations, and the local community. The local community is very important here because it should be committed to the brand values that are delivered to the market (Tsiotsou \& Goldsmith, 2012).

Brand structure is influenced by both marketing and pro-quality activities (Panasiuk, 2013, pp. 21-30). Marketing statements are picked up by the service providers and used to refine their own offerings and differentiate them from their competitors, while retaining entrepreneurial identity.

The destination assumes general communication. Therefore, the positive reputation of a place brand not only affects consumer behaviour, contributing, for example, to the intensification of tourism, but also builds place competitiveness, it can gain a differential advantage over its competitors (Greaves \& Skinner, 2010, pp. 486-507). It determines the development of a given region, influencing, among others, the number of investments.

The basic decisions related to building the tourist brand strategy include (Panasiuk, 2007):

- description of the destination to be branded,

- ways of identifying the brand,

- market reach of the brand's impact,

- brand positioning,

- the communication marketing instruments supporting the brand,

- brand development.

In this order, in the next part of the article, activities focused on building the brand of the South Coast Baltic region will be presented.

Building the brand of SCB is carried out as part of the South Coast Baltic project.

\section{Description of the South Coast Baltic project}

South Coast Baltic (Establishing durable cross-border boating destination management on the basis of the MARRIAGE cooperation network) project is financed under Interreg South Baltic Programme 2014-2020. It began in October 2016 and will be completed on September 30,2019 . The total budget amounts to more than 2.5 million 
euros The leading partner is Economic Development Corporation Vorpommern (DE). The project involves fourteen project partners, from Denmark (1), Germany (4), Poland (7), and from Lithuania (2) as well as ten associated partners covering all five programme countries. The partnership consists of local authorities, universities, tourist and sport organisations, and marina management. The core partners are supported by 8 associated partners such as tourism organisations, NGOs operating in the tourism sector, harbour, marina, and local authorities. The overall idea of the project is to make the cross-border boating region durably attractive through establishing a comprehensive cross-border destination management which would combine joint marketing, the aim of which is e.g. brand development, with improvements of boating services and infrastructure. Thus, all entities involved in the project are part of DMO which was set up for the project implementation purpose and which is planned to have a permanent form after its completion.

\section{The task of brand development for the destination}

Project activities are expected to give a 20\% rise in the number of guest boaters visiting the South East Baltic coast by 2019 and thereby level up the sailing figures in the whole South Baltic area (see: https:// southbaltic.eu).

The project is a continuation end extension of the MARRIAGE project (better marina management, harbour network consolidation and water tourism marketing in the Southern Baltic rim) which was implemented in 2011-2015.

This also applies to activities undertaken in the area of branding process, which was started in the MARRIAGE project.

The implementation of this objective is subject to the measures shown in Figure 1.

Activities undertaken within the framework of SCB at the level of education and investment can be considered as pro quality activities that will lead the people to a promised brand.

In terms of education, educational activities will be provided - not only for marina staff, but also for students. Activities will be focused on increasing the level of customer satisfaction, but also on supporting sustainable development of the region to raise awareness of these issues for current and future employees of the marinas. 


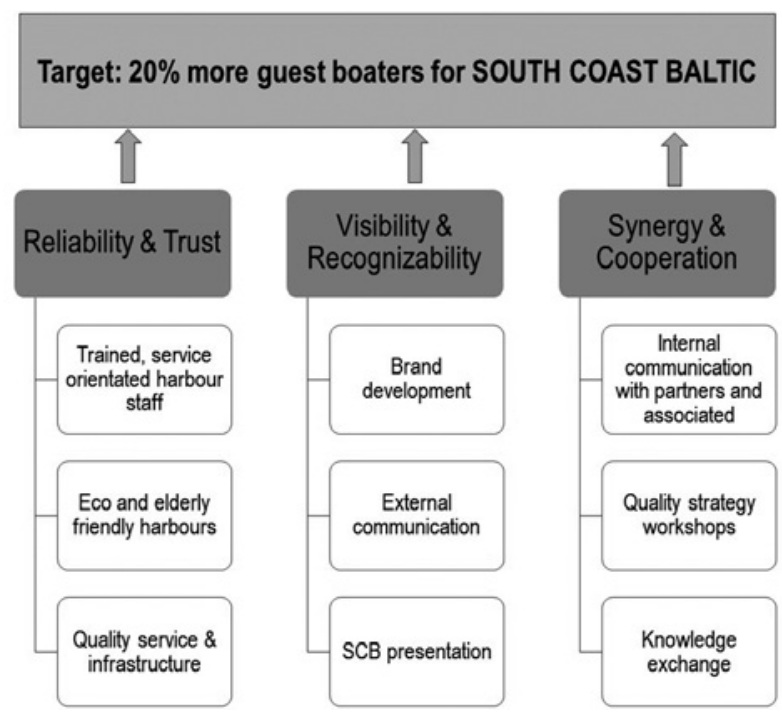

Figure 1. Measures of the South Coast Baltic image building Source: own study.

In terms of investment it is planned to invest in pilot investments that will provide facilities for the elderly-friendly solutions at selected marinas. This is important because the growing share of sailing seniors has been confirmed by research conducted in Germany in 2013 (Wassertourismus..., 2013). A very important issue is that in chosen marinas pilot eco-friendly investments will also be made. In the frame of the SCB project an environmental certification of the marinas will also be made. It is planned that four pilot certificates will be implemented and set a common SCB standard.

All these activities are meant to make the South Coast Baltic brand credible and encourage tourists to return to this destination.

The main goal to be achieved through the appropriate creation of the brand and marketing activities undertaken within this framework is already mentioned - a $20 \%$ increase in guest boaters in the region by the end of 2019. Additional goals are to increase guest boaters from Scandinavian countries (Sweden, Denmark, and Finland), increase the numbers of guest boaters from Germany, Poland, Lithuania, and Russia, increase the numbers of guest motor boaters and increase the charter guests and identify the number of charter opportunities. There is also a secondary goal which is the increase of the numbers 
of boaters with permanent berth in the region (sailors, motor boaters, and where it is possible mega yachts).

\section{Identification of the destination to be branded}

The area defined as the southern shores of the Baltic Sea, comprises the coastal sections of the regions (from West to East): Vorpommern (DE), Zachodniopomorskie (PL), Pomorskie (PL), Region Klaipeda (LT), Oblast Kaliningrad (RU), and Bornholm (DE) as a stop over from Sweden to Germany, Poland, Russia or Lithuania, or the other way around and also a destination for the boaters coming from the South Coast Baltic regions.

The term "South Coast Baltic", the Southern East coast, in that case is a marketing term and it helps to create a profile of this destination. However, it would not be possible to exactly define it nautically, geographically, or non-geologically. It is a matter for brand development to fill this term and to produce an image for the boaters to get an emotional response.

\section{Ways of identifying the brand}

The perception of the brand has the goal that it is recognised easily by the customers. The brand description consists of 4 components (Figure 2):

- the brand values,

- the given conditions,

- the fields of experiences,

- $\quad$ the core - or the essence - of the brand.

As we talk about a brand development with 5 countries a common denominator of those 4 brand components was e established by all partners. What had been already established in the first step in the MARRIAGE project has now been tuned and more focused in the next step of the brand development.

The visibility and the recognition factors of the brand are the following: the logo and SCB motto, colour schemes, visual language, corporate wording, and style of material.

The logo and the motto "where boating adventure begins" have been reviewed against the background of the next step of brand development. The motto is also the essence of the brand and adverts to the fact that sailing along the southern shores of the Baltic Sea is 
still rather unusual, but boating is every time an adventure. The logo symbolises a sailing ship (red dot) and the waves (blue part waves) and it is shown in Figure 3. In the same time the colours and the different elements (the waves, red dot) can be used for other purposes, e.g. brochures of the partners.

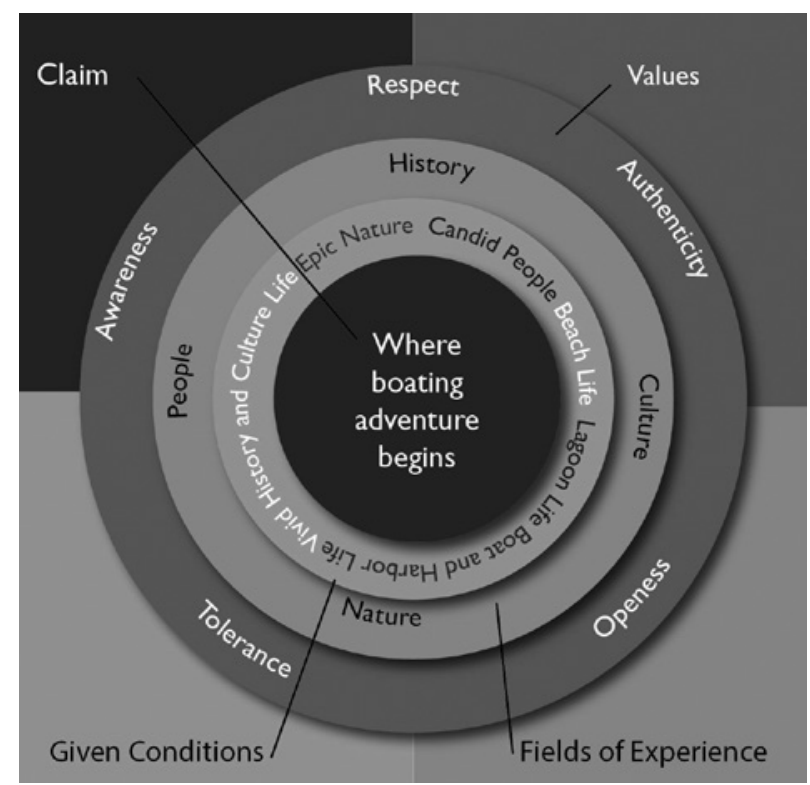

Figure 2. Components of SCB brand

Source: own study.

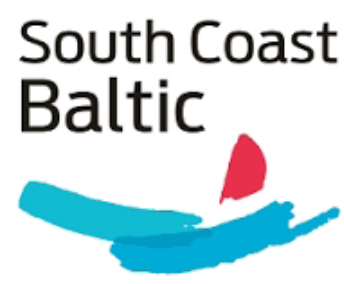

Where boating adventure begins

Figure 3. SCB Logo

Source: Jamel Interactive Sp. z o.o., https://www.jamel.pl/en/\#/en/19/c,14/portfolio/branding (accessed: 10th April 2018). 
The colour scheme is based on the corporate design, an output of the SCB logo. The use of the same colour schemes leads to a unified visibility of the umbrella brand.

The visual language is the core for the identification and recognition of South Coast Baltic. Through the visual language (photos, videos etc.) the customers are emotionally addressed and a curiosity is aroused to learn more about the depicted contents. The visual language should therefore be surprising and contractual, rather unexpected to show in order to remain so in memory. The selected photo (and also video) material will range in the specified fields of experiences (see brand components). The selected visual language of the umbrella brand SCB is a proposal for the sub regions to get in this way visibility through the umbrella brand. Therefore, the key visuals for the brand and suggestions for the already existing brands of the sub regions had been selected in close cooperation with all partners.

According to the diversity and the idea of a contrasted visual language also the corporate wording is based on this main idea. A contrasting language bring pictures to life in the mind of the audiences. In consequence texts' contents avoid platitudes and generalities, but they are verifiable, proofed, and concrete.

Personal stories and a glimpse behind the normal touristic information helps to get in close contact with the audience. Here, also the brand value's "authenticity" will be represented by choice of texts and the stories that will be chosen in the "fields of experience" from the brand.

SCB's information material takes in consideration the established corporate design, the different aspects of the brand description, the visual language, and the corporate wording. The material is the point where the brand is brought to life and where the visibility and the recognition of the SCB becomes reality.

\section{Market reach of the brand's impact}

As mentioned earlier, the process of building the SCB brand started as part of the MARRIAGE project. As shown in the survey conducted on one day - in July 2017 in 70 harbours in six regions among 1,188 boaters from a total of 15 countries on 420 boats that came from 10 countries, the SCB brand is well recognized.

The results of the surveys show that already $419 \%$ of the boaters had already heard about SCB before. Certainly, there may be doubts 
as to how many tourists really recognise the brand, and to what extent the name SCB is associated with the geographical region. Nevertheless, the results of the study are very optimistic and on its basis it can be considered that the marketing campaign has been already successful after the first step which was completed in 2015 . Iinterest in this region increased noticeably, but there is still potential for a higher increasing.

The next step will be to get a higher visibility and recognition of SCB.

The SCB project has redefined the target groups. These are:

- sailors / boat owners,

- sailors / charter guests,

- motor boaters / boat owners,

- motor boaters charter guests, coming from Germany, Poland, Russia, and Lithuania and beyond and also from Scandinavia (Sweden, Denmark, and Finland).

On the basis of research carried out as part of the MARRIAGE project, the flow of tourists between borders was determined, i.e. the representatives of which nationalities most often visit individual regions. The division into sailors and motor boaters was taken into account (table 1). This data can be considered as the starting point for the SCB project. However, it was impossible to distinguish between yacht users and owners and charter guests, because the previous project did not introduce such a distinction.

Table 1. The structure of the nationality of sailors visiting yacht harbours in individual regions

\begin{tabular}{|l|r|r|r|r|r|r|r|r|r|r|r|r|r|r|}
\hline \multirow{2}{*}{ Region } & \multicolumn{9}{|c|}{ Nationality of sailors (\%) } & \multicolumn{9}{c|}{ Nationality of motor boaters } \\
\cline { 2 - 15 } & DE & PL & SE & DK & LT & RU & Other & DE & PL & SE & DK & LT & RU & Other \\
\hline $\begin{array}{l}\text { Vorpommern } \\
\text { (DE) }\end{array}$ & $80-90$ & 8 & 6 & - & - & - & - & 85 & 5 & 2.5 & 2.5 & - & - & 5 \\
\hline $\begin{array}{l}\text { Zachodniopomor- } \\
\text { skie i Pomorskie } \\
\text { (PL) }\end{array}$ & 20 & 70 & 5 & 5 & - & - & - & 15 & 80 & 1 & - & - & 2 & 3 \\
\hline Bornholm (DK) & 20 & 10 & 10 & 50 & - & - & 10 & 10 & 20 & - & 40 & - & - & 30 \\
\hline $\begin{array}{l}\text { Klaipeda region } \\
\text { (LT) }\end{array}$ & 5 & 2 & 2 & - & 90 & - & 1 & - & - & - & - & 99 & - & 1 \\
\hline $\begin{array}{l}\text { Kaliningrad } \\
\text { region (RU) }\end{array}$ & - & - & - & - & - & 99 & 1 & 5 & 5 & - & - & - & 85 & 5 \\
\hline
\end{tabular}

Source: own work. 
Then it was necessary to determine their habits. Representatives of individual target groups differ significantly on some issues as presented in the XX and YY tables depicting classification and typology of the boaters (with a distinction between sailors and motor boaters), but of course they also have some common features which also needs to be taken into consideration.

The typology of boaters from various target groups has been prepared on the basis of observations of the project partners. The groups of sailors, most often coming to yacht harbours belonging to the SCB region, have been distinguished, as well as their preferences and their most common sailing behaviour. Table 2 presents the types and characteristics of sailors (with a distinction between boat owners and charter guests), and table 3 motor boaters (prepared according to the same scheme).

Table 2. Types and characteristics of sailors

\begin{tabular}{|c|c|}
\hline \multicolumn{2}{|r|}{ Sailors } \\
\hline \multicolumn{2}{|r|}{ Boat owners } \\
\hline Type & Characteristic \\
\hline $\begin{array}{l}\text { Young sailors, } 30-40 \\
\text { years old }\end{array}$ & $\begin{array}{l}\text { - like to sail independent on the weather conditions } \\
\text { - are mostly unexperienced (parents' boat) and like to } \\
\text { experience boating life } \\
\text { - curious to see new places }\end{array}$ \\
\hline $\begin{array}{l}40 \text { years old until the time } \\
\text { of pension, } 1-3 \text { (max.) } \\
\text { weeks holiday }\end{array}$ & $\begin{array}{l}\text { - plan their trips carefully, they avoid heavy weather or } \\
\text { they remain in the harbour. } \\
\text { - like to sail } \\
\text { - like to stay in cosy harbours and non-crowded places. }\end{array}$ \\
\hline $\begin{array}{l}40-50 \text { year-old couples } \\
\text { going for } 1-2 \text { weeks }\end{array}$ & $\begin{array}{l}\text { - prefer crowded places } \\
\text { - mostly interested in culture and history } \\
\text { - the safer the place the more they spend }\end{array}$ \\
\hline $\begin{array}{l}\text { Elderly people (pension- } \\
\text { ers) with a lot of time }\end{array}$ & $\begin{array}{l}\text { - prefer uncrowded places with unspoiled nature nearby } \\
\text { - do not fear open water but prepare their trips carefully }\end{array}$ \\
\hline $\begin{array}{l}\text { Grandparents with grand- } \\
\text { children }\end{array}$ & $\begin{array}{l}\text { - avoid dangerous situations } \\
\text { - set sail when the weather is calm otherwise, they remain } \\
\text { in the harbour } \\
\text { - like to also find offers for children on land (fun parks etc.) }\end{array}$ \\
\hline Sailing pioneers & $\begin{array}{l}\text { - sail regardless of the weather or wind conditions, their } \\
\text { motivation: stay on a boat and sail! }\end{array}$ \\
\hline $\begin{array}{l}\text { Families, } 1-2 \text { children or } \\
\text { teens with friends, } 1-2 \\
\text { weeks holiday / weekends }\end{array}$ & $\begin{array}{l}\text { - like to stay in harbours where the beach is close by } \\
\text { - normally avoid heavy weather on the sea and stay in the } \\
\text { harbours longer }\end{array}$ \\
\hline
\end{tabular}


Table 2. cont.

\begin{tabular}{|c|c|}
\hline \multicolumn{2}{|r|}{ Sailors } \\
\hline \multicolumn{2}{|r|}{ Boat owners } \\
\hline Туре & Characteristic \\
\hline \multicolumn{2}{|r|}{ Charter guests } \\
\hline $\begin{array}{l}40 \text { to } 60 \text { years old, } 6 \text { peo- } \\
\text { ple } 1 \text {-week charter, }\end{array}$ & $\begin{array}{l}\text { - do not live at the coast, they arrive mostly far away } \\
\text { - like to sail on the boat with friends } \\
\text { - eat and drink on the boat and do not use the services } \\
\text { (restaurants) in the harbour }\end{array}$ \\
\hline $\begin{array}{l}6-8 \text { people, men or } \\
3 \text { couples }\end{array}$ & $\begin{array}{l}\text { - prefer big boats } \\
\text { - prefer good infrastructure in the harbour } \\
\text { - spend money in restaurants and bars } \\
\text { - prefer harbours close to sandy beaches }\end{array}$ \\
\hline $\begin{array}{l}\text { Family crews for boating } \\
\text { holiday }\end{array}$ & The same as type 7 of boat owners \\
\hline $\begin{array}{l}\text { Young couples for boating } \\
\text { holiday }\end{array}$ & The same as type 1 of boat owners \\
\hline
\end{tabular}

Source: own work.

Table 3. Types and characteristics of motor boaters

\begin{tabular}{|c|c|}
\hline \multicolumn{2}{|r|}{ Motor boaters } \\
\hline \multicolumn{2}{|r|}{ Boat owners } \\
\hline Type & Characteristic \\
\hline $\begin{array}{l}\text { Elderly boaters (former sail- } \\
\text { ors) from } 70 \text { years up }\end{array}$ & $\begin{array}{l}\text { - like comfort and they fear heavy weather, they nor- } \\
\text { mally stay in the harbours on the boats }\end{array}$ \\
\hline $\begin{array}{l}\text { Passione motor boaters, from } \\
40 \text { years old }\end{array}$ & $\begin{array}{l}\text { - large boats, convinced motor boaters, stay } 1-2 \text { weeks } \\
\text { on the boat } \\
\text { - appreciate comfort and well feeling }\end{array}$ \\
\hline Sport fishers & $\begin{array}{l}\text { - prefer calm see (often lagoons) } \\
\text { - but they also do not fear open water, 1-30 days, } \\
\text { mostly they arrive with a trailer / car, stay overnight } \\
\text { in hotel or on a campsite (boats are too small) }\end{array}$ \\
\hline $\begin{array}{l}\text { Young boaters with speed } \\
\text { boats (going on open water) }\end{array}$ & $\begin{array}{l}\text { - they like nightlife and parties, they just go out for } \\
\text { short trips and then they turn in the harbours. }\end{array}$ \\
\hline \multicolumn{2}{|r|}{ Charter guests } \\
\hline $\begin{array}{l}\text { Elderly Couples ( } 1-2 \text { couples), } \\
\text { weekend, } 1 \text { week charter }\end{array}$ & $\begin{array}{l}\text { - they like going by boat without a boat licence to } \\
\text { experience new places } \\
\text { - they are curious and they like to make a new experi- } \\
\text { ence with boating } \\
\text { - they like to spend their holiday with new cultural } \\
\text { experiences }\end{array}$ \\
\hline
\end{tabular}

Source: own work. 
Such a precise definition of target groups was necessary for the further development of the brand development process. This allows choosing the right marketing tools that will allow to effectively influence individual groups of buyers.

\section{Brand positioning}

Due to the uniqueness of this international based destination brand development described, consisting in the fact that it covers regions with different characteristics and belonging to five countries, it was impossible to carry out activities in the field of brand positioning and comparing it to other market brands. To the Authors' knowledge, this is the only brand referring to such a complex area product, so it is impossible to find a brand to compare it with. In this case, one can talk about the "umbrella" brand unifying couple of very different destinations.

\section{The scope of marketing instruments supporting the brand}

Achieving a strong, umbrella brand unifying couple of destinations needs to refine and coordinate the proper communication approach which is implemented with the support of various marketing instruments. The article will focus on the promotion and marketing communication tools used. It should be remembered that in the case of SCB, the brand had to take into account sub regional positioning. The marketing tools used are designed to support internal and external communication. In the case of internal communication, the recipients were divided into two groups: partners of the sub-regions and the marina managers who, due to direct contacts with boaters, play a key role in creating the brand (Figure 4).

As mentioned earlier, the SCB brand refers to a very specific product consisting of regions belonging to different countries. The habits of their inhabitants are very different. It is impossible to create a single, common scheme of using marketing tools for external communication. Their application has been diversified and adapted to the needs of individual regions.

It is interesting to note that one of the tools classified as internal communication was used for this purpose, namely the partner workshop. During the meeting, partners from various regions were invited 
(Vorpommern (GE), Zachodniopomorskie and Pomorskie regions (PL), Bornholm (DE) and Lithuania dealing with representatives of various local target groups on a daily basis to identify the most effective communication tools in a given region. The tools were rated on a scale from 1 to 10. The results of the expert study are shown in Figures 5-7.

Destination brand building process: SOTH COAST BALTIC

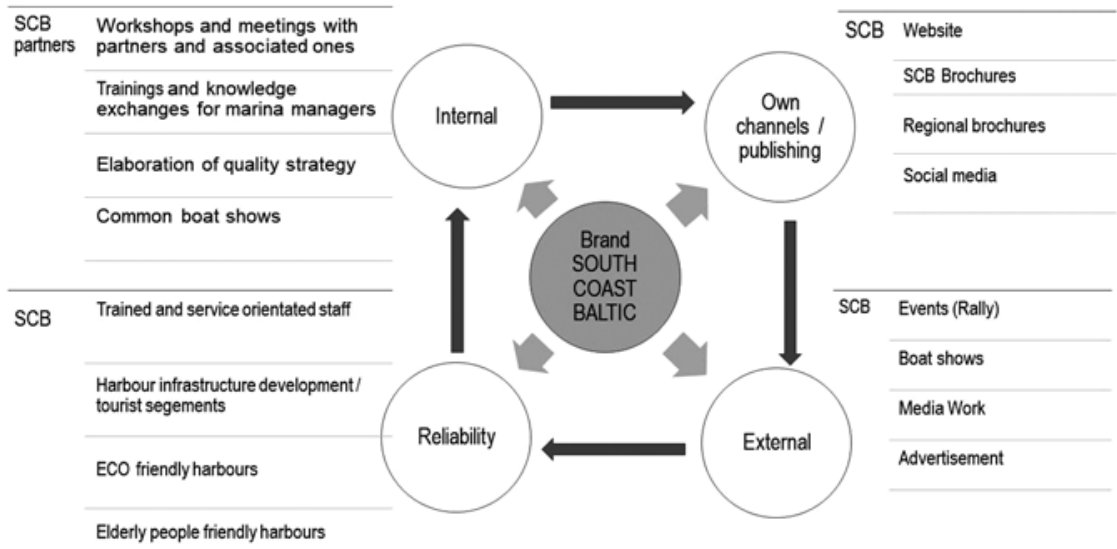

Figure 4. Process of destination brand implementation of South Coast Baltic Source: own work.

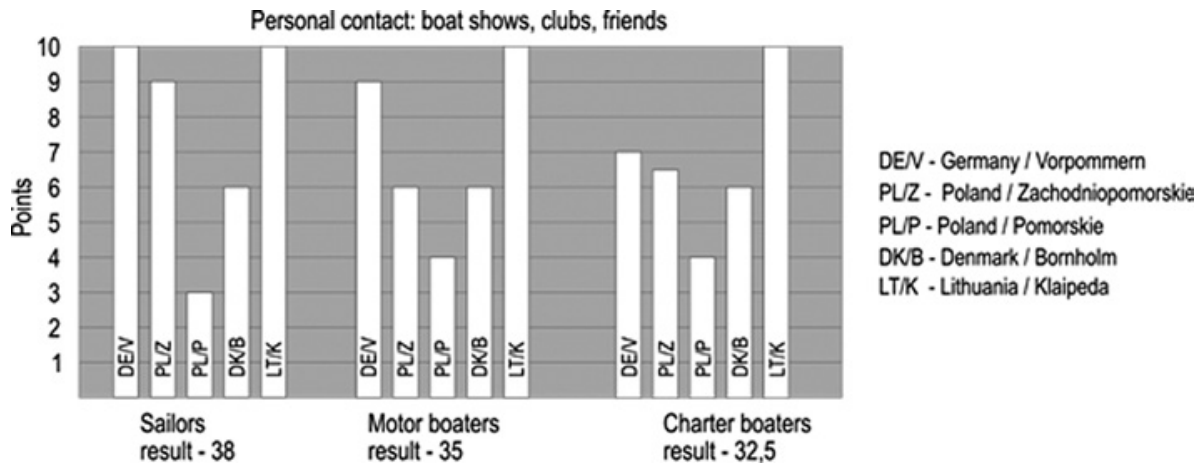

Figure 5. Regional experts' opinion about effectiveness of personal contact tools 


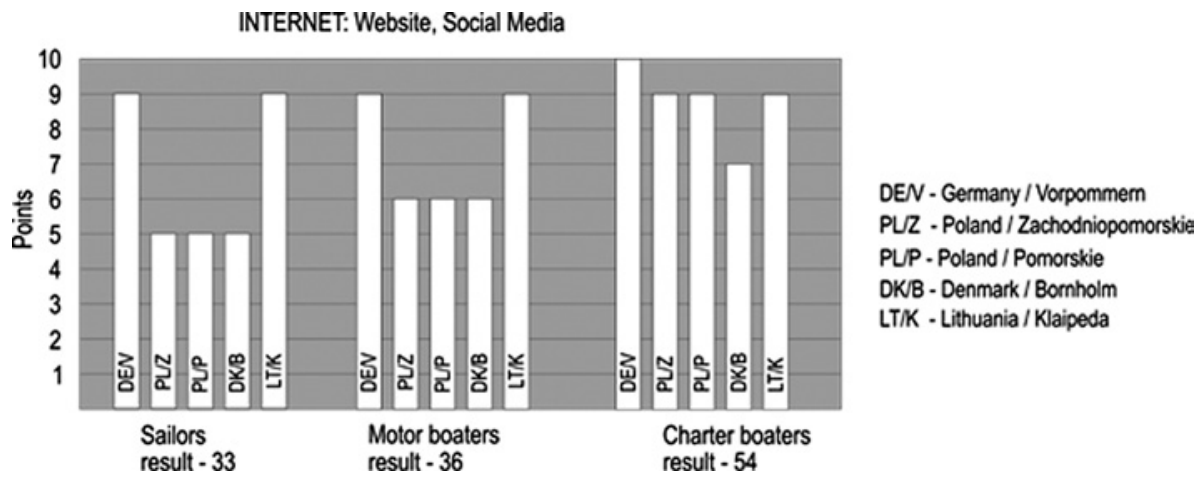

Figure 6. Regional experts' opinion about effectiveness of Internet tools Source: own work.

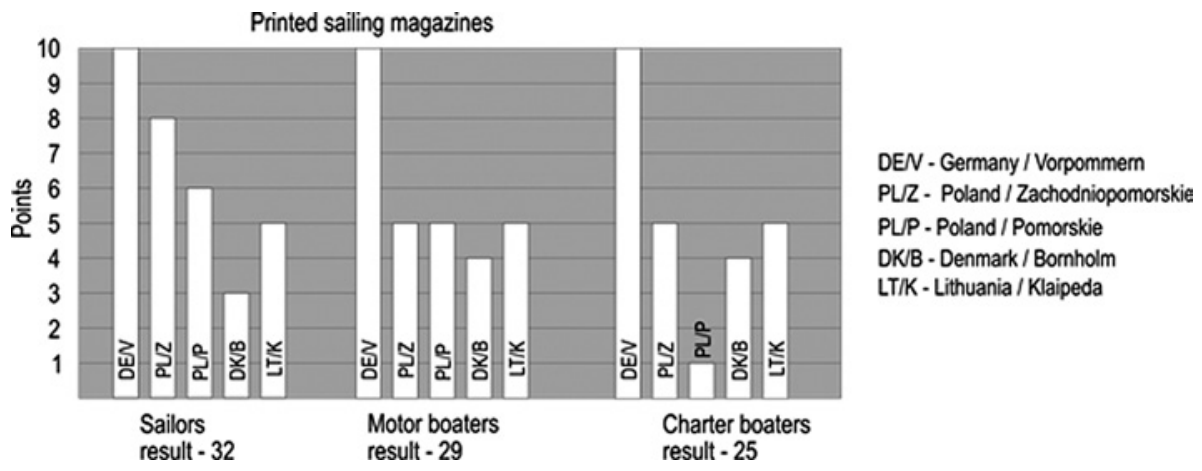

Figure 7. Regional experts' opinion about effectiveness of printed sailing magazines

Source: own work.

According to the study, the personal contact is the most important way to reach all boaters, but especially the Lithuanian and the German sailors and motor boaters (9 to 10 points). The sailing fairs are certainly an effective element here. This is due to their interactivity. The fair allows direct contact with customers, giving the opportunity to tailor the message to the needs of a specific recipient (Gębarowski, 2010, p. 11).

The boat shows in Germany, Poland, Sweden, and Denmark - based on these data - are identified as the most effective marketing instrument for the implementation of the brand. It is the right platform to contact 
not only tourists but also the media representatives and at least the boat show gives the chance for an intensive internal communication due to the fact that several representatives from the other "area products" will participate at the several fairs.

For the promotion of SCB the participation of minimum eight of the most important boat shows in Germany (boot Düsseldorf 2017-2019), Sweden (Allt för sjön 2018, 2019), Poland (Wiatr i Woda 2017-2019) and Denmark (Frederecia boat show 2019) including events at the stand, were indicated.

Today the Internet is the most important source for collecting information. So, it is for SCB. This fact was shown also by the experts who valued the Internet as one of the most important channel where the boaters and especially those who are interested in charter possibilities get their information from (54 points). But, especially in Germany - the boaters still prefer printed media as the most reliable channel to stay informed (10 points each).

\section{Brand development}

The brand was created and started to be developed as part of the MARRIAGE project in 2012, this process has been continued since 2016 as part of the SCB project. When it comes to brand extension, target groups have been added: motor boaters, charter boaters, and boaters from Sweden. It was recognised that the Swedish market has a great potential and that many boaters from that region can be interested in SCB's offer.

To ensure a sufficient quality of the offered tourist product and its matching the customers' needs, surveys are conducted at the yacht harbours in the SCB region. They are intended to provide knowledge about the preferences of boaters. Such research was conducted in July 2017. The research covered 420 boats in 70 harbours in 6 regions. The surveys will be continued in 2018 and 2019. They are in the same time the controlling instrument for the selected instruments to reach the main target of increasing the number of boaters in the southern shores of the Baltic Sea. 


\section{CONCLUSIONS}

Destination branding is a long-lasting and comprehensive process because it concerns the most complex tourist product which in fact destination is. It involves various other tourism products and various entities what requires a special approach.

In the paper basing on the study case method a complex process of the brand development was shown and the results of research that was carried out to support the undertaken marketing activities were presented. It concerns the South Coast Baltic brand which is unique because not only one destination as a national entity is included, but in fact five countries with their complex touristic structure. The focus on the whole region as a water sports region makes the SCB brand very special.

The process began in 2012 with the MARRIAGE project and forms the basis for the next step, SCB's marketing initiative which has a strong focus on the marketing of the region. But that is not the end of the brand development process. After all, the umbrella brand SCB can only represent what the partners involved or here: tourism products bring in terms of quality, credibility, and authenticity.

This process is subject to constant change and further development which is ultimately based on the wishes and requirements of the target group of boaters. The prerequisite for this is continuous internal communication, a review of the effectiveness of the instruments used and continuity of the marketing communication of the umbrella brand.

\section{ACKNOWLEDGMENTS}

The paper is a part of the research project under the title "South Coast Baltic - Establishing durable cross-border boating destination management on the basis of the MARRIAGE cooperation network", funded by the European Commission's Interreg South Baltic Programme 2014-2020 under grant agreement No STHB. 02.01.00 - DE $-0070 / 16$ 


\section{REFERENCES}

Campelo, A. et al. (2013). Sense of place: The importance for destination branding. Journal of Travel Research, 53(2), 154-166.

Dębski, M. (2013). Jakość jako element budowania marki destynacji podczas kryzysu gospodarczego. International Journal of Contemporary Management, 12(1), 41-50.

Düssel, M. (2009). Marketing w praktyce. Tłum. B. Moryl. Warszawa: BC Edukacja.

Dwyer, L. \& Kim, C. (2003). Destination competitiveness: Determinants and indicators. Current Issues in Tourism, 6(5), 369-414.

Erdem, T. \& Swait, J. (2004). Brand credibility, brand consideration, and choice. Journal of Consumer Research, 31(1), 191-198.

Gębarowski, M. (2010). Wspótczesne targi: Skuteczne narzędzie komunikacji marketingowej. Gdańsk: Regan Press.

Greaves, N. \& Skinner, H. (2010). The importance of destination image analyses to UK rural tourism. Marketing Intelligence \& Planning, 28(4), 486-507.

Kaczmarek, J., Stasiak, A. \& Włodarczyk, B. (2005). Produkt turystyczny. Pomyst. Organizacja. Warszawa: PWE.

Khan, B.M. (2009). Corporate brand management: Past, present and future. Pranjana: The Journal of Management Awareness, 12(1), 21-39.

Kotler, P. \& Gertner, D. (2002). Country as brand, product and beyond: A place marketing and brand management perspective. In: N. Morgan, A. Pritchard \& R. Pride. Destination Branding: Creating the Unique Destination Proposition, 2 (pp. 40-56). Oxford: Elsevier.

Michalski, E. (2017). Marketing. Warszawa: WN PWN.

Morgan, N., Pritchard, A. \& Pride, R. (2011). Destination Brands: Managing Place Reputation. London-New York: Routledge.

Morgan, N.J., Pritchard, A. \& Piggott, R. (2003). Destination branding and the role of the stakeholders: The case of New Zealand. Journal of Vacation Marketing, 9(3), 288-295.

Panasiuk, A. (red.) (2007). Marketing ustug turystycznych. Warszawa: WN PWN.

Panasiuk, A. (2013). Marka turystyczna jako instrument zarządzania regionalna gospodarką turystyczną w warunkach sytuacji kryzysowych. International Journal of Contemporary Management, 12(1), 21-30.

Scherhag, K. (2000). Profilierungsstrategien für touristische Regionen. In: M.L. Fontanari, K. Scherhag, G. Verlag (Hrsg.). Wettbewerb der Destinationen (pp. 149-162). Wiesbaden: Springer Fachmedien.

Tsiotsou, R.H. \& Goldsmith, R.E. (eds.) (2012). Strategic Marketing in Tourism Services. [s.1.]: Emerald. 
Wassertourismus in Deutschland. Praxisleitfaden für wassertouristische Unternehmen, Kommunen und Vereine (2013). Berlin: Bundesministeriums für Wirtschaft und Technologie, https://southbaltic.eu (accessed: 10th April 2018).

https://southbaltic.eu (accessed: 10th April 2018).

https://www.jamel.pl (accessed: 10th April 2018). 